\title{
The Contribution of Geothermal Heat Pumps in Net Zero Energy Buildings (NZEBs)
}

\author{
Diana D'Agostino ${ }^{1}$, Luigi Mele ${ }^{2}$, Francesco Minichiello ${ }^{1}$ \\ ${ }^{1}$ University of Naples Federico II, Department of Industrial Engineering, Piazzale Tecchio 80, \\ 80125 Napoli, NA, Italy \\ ${ }^{2}$ Freelance engineer, Napoli, Na, Italy
}

\begin{abstract}
The aim of this work is to analyse the energy contribution of a geothermal heat pump for heating and cooling in a Net Zero Energy Building (NZEB) used as B\&B, through a dynamic energy simulation software (DesignBuilder).

The case study building is virtually located in two Italian cities with different climatic characteristics. The energy savings related to the use of the geothermal heat pump are evaluated, compared to both an air-to-water heat pump and a condensing boiler coupled to a chiller. In literature there are few comparisons between air-to-water heat pump and geothermal heat pump. The paper evaluates how much this technology is convenient for NZEBs, from an energetic-economic point of view.
\end{abstract}

\section{Introduction}

In the European Union the building stock is responsible for around $36 \%$ of all $\mathrm{CO}_{2}$ emissions. The European Directive 2018/844 (2018) on the energy performance of buildings, in the wake of the two previous directives, the so-called "EPBD" (2002) and "EPBD recast" (2010), sets the goal to totally decarbonise this building stock by 2050 .

This is done by making existing buildings nearly Zero Energy Buildings (nZEBs) and using mostly energy from renewable sources (Hermelink et al, 2013). The target of Net Zero Energy Building (NZEB) seems instead still far to be reached.

A NZEB is defined as a building with very high energy performance whose low energy needs are entirely met by renewable sources (Torcellini et al, 2006). This is difficult to achieve because there are numerous parameters to be defined: the control volume on which the energy balance is to be carried out; whether this balance should be annual (Mohamed et al, 2014), seasonal or monthly; if only onsite renewable energy sources can be used (D'Agostino et al, 2017); what are the most suitable technologies to reach the NZEB target (Ferrante et al, 2011). In particular, in Italy, unlike what happened for the nearly zero energy building, there is still no legislative prescription to define a NZEB.

It is very important to reduce the energy needs of a building to reach the NZEB target. Ascione et al (2016) highlighted the boundary conditions, concepts and design criteria for a NZEB, showing how a good project can generate a very low energy demand for the heating and cooling of the building. In Buonomano et al (2015), the energy requirements obtained for heating and cooling were respectively 3.9 and $6.7 \mathrm{kWh} / \mathrm{m}^{2} \mathrm{y}$, for a nonresidential NZEB in Mediterranean climates.

Fedajev et al (2016) analysed the impact of several ground heat exchangers coupled with a geothermal heat pump and a thermal storage in a nZEB. They highlighted the importance of a thermal storage to rise the nZEB target in very harsh climates like the Finnish one.

In literature there are few comparisons between the geothermal heat pump (GSHP, i.e. Ground Source Heat Pump) and a classic technology such as the air-to-water heat pump, mostly in a NZEB. For this reason, the aim of this paper is to evaluate the energy saving related to the use of a GSHP for a NZEB, compared to both the case of air-to-water heat pump and that of condensing boiler coupled to a chiller. A case study building virtually located in two Italian cities with different climatic characteristics is simulated. Also, a technical-economic comparison is carried out, through the simple and discounted payback analysis.

\section{Methodology}

The aim of this work is to evaluate the seasonal energy contribution of a geothermal heat pump to achieve the target of NZEB, with reference to a case study.

First, it is necessary to design a building that has low energy requirements. For this reason, the case study building envelope is characterized by optimal thermal characteristics, which maximize the free heat gains in winter and reduce them in summer; therefore, a compact form, an optimal insulation and innovative technologies are chosen.

The heating, ventilation and air-conditioning (HVAC) systems must be subsequently designed in order to reduce the primary energy demand, using energy- efficient devices, and this is precisely the core of the described research.

The insertion of a geothermal heat pump into an energyefficient building is evaluated to assess whether, using this technology, it would be easier to achieve an energy balance equal to zero between energy produced from renewable sources and energy required by the buildingplants system.

In this regard, the energy needs of the case study building (virtually located in two climatic zones) are evaluated. The energy analysis is carried out using a dynamic simulation software (DesignBuilder), based on EnergyPlus as a calculation engine. Several validation 
tests are available (U.S. Department of Energy, 2011, ab) for EnergyPlus. The reference climatic parameters are taken from the ASHRAE (2017).

The core of the research is an energy comparison between different thermal energy generators: a ground source heat pump with vertical boreholes, an air-to-water heat pump and a condensing boiler coupled to a chiller.

With reference to the used dynamic simulation software (DesignBuilder), a conduction transfer function module (CTFM) is set. It uses the algorithm called "conduction transfer function". Instead, the algorithm TARP (2018) is used for the inside convection and the algorithm DOE-2 (2016) for the outside convection.

The modelling approach considered in DesignBuilder for the heat pumps uses an equation-fit based model (Tang 2005, Jones 2013) to obtain the heating and cooling capacity $\dot{Q}$ and consequently the power:

$$
\dot{Q}=C_{1}+C_{2} \frac{V_{L}}{V_{\text {ref }}}+C_{3} \frac{V_{S}}{V_{\text {ref }}}+C_{4} \frac{T_{L}}{T_{\text {ref }}}+C_{5} \frac{T_{S}}{T_{\text {ref }}}
$$

where:

$\mathrm{C}_{1-5}$ are constants;

$\mathrm{L}$ and $\mathrm{S}$ refer to load and source side respectively; ref is used for reference conditions;

$\mathrm{V}$ is the volumetric flow rate;

$\mathrm{T}$ is the temperature.

As can be seen, the equation (1) shows a linear relationship between temperature and power.

To define the seasonal efficiency of a geothermal heat pump, it is necessary to calculate the temperature of the ground. The formula of Kusuda (1965) has been used:

$$
\begin{aligned}
T_{g}(D, t)= & T_{m}-A \cdot \exp \left[-D \cdot \sqrt{\frac{\pi}{365 \cdot \alpha_{g}}}\right] \cdot \cos \left[\frac{2 \pi}{365} .\right. \\
& \left.\left(t-t_{T_{\min }}-\frac{D}{2} \cdot \sqrt{\frac{365}{\pi \cdot \alpha_{g}}}\right)\right]
\end{aligned}
$$

where:

- $\quad \mathrm{T}_{\mathrm{g}}(\mathrm{D}, \mathrm{t})=$ soil temperature at a depth $\mathrm{D}$ after $\mathrm{t}$ days starting from the first day of January $\left[{ }^{\circ} \mathrm{C}\right]$;

- $\mathrm{T}_{\mathrm{m}}=$ annual average temperature of the outdoor environment according to statistical data $\left[{ }^{\circ} \mathrm{C}\right]$;

- $\mathrm{A}=$ amplitude of annual oscillation of the temperature $\left[{ }^{\circ} \mathrm{C}\right]$;

- $\mathrm{t}=$ sequential number of the day $\left(1^{\text {st }}\right.$ of January $\left.=1\right)$;

- $\mathrm{t}_{\mathrm{T} \min }=$ sequential number of the day corresponding to the minimum soil temperature, found on the basis of statistical information ( 1 st of January $=1)$;

- $\quad \mathrm{D}=\operatorname{depth}[\mathrm{m}]$;

- $\alpha_{\mathrm{g}}=$ equivalent daily thermal diffusion of the soil $\left[\mathrm{m}^{2} /\right.$ day $]$.

In Table 1 the values used for the above mentioned parameters are shown.
Table 1: Soil temperatures and different parameters which influence the efficiency of the GSHP.

\begin{tabular}{ccc}
\hline & Palermo & Milan \\
\hline $\mathrm{T}_{\mathrm{m}}$ & $18,6^{\circ} \mathrm{C}$ & $12,5^{\circ} \mathrm{C}$ \\
$\mathrm{A}$ & $5,1^{\circ} \mathrm{C}$ & $9,4^{\circ} \mathrm{C}$ \\
& 15 & 15 \\
$\mathrm{t}_{\mathrm{T} \text { min }}$ & $\left(\right.$ January $\left.15^{\text {th }}\right)$ & $\left(\right.$ January $\left.15^{\text {th }}\right)$ \\
$\mathrm{D}$ & $80 \mathrm{~m}$ & $80 \mathrm{~m}$ \\
$\mathrm{t}$ & $335\left(\right.$ December $\left.21^{\mathrm{st}}\right)$ & $335\left(\right.$ December $\left.21^{\text {st }}\right)$ \\
$\alpha_{\mathrm{g}}$ & $0,0821 \mathrm{~m}^{2} /$ day & $0,0821 \mathrm{~m}^{2} /$ day \\
$\mathrm{T}_{\mathrm{g}}(\mathrm{D}, \mathrm{t})$ & $19^{\circ} \mathrm{C}$ & $13{ }^{\circ} \mathrm{C}$ \\
\hline
\end{tabular}

The seasonal energy efficiencies of the heat pump and refrigerating group are evaluated as follows (SCOP for heating mode, SEER for cooling mode):

$$
\begin{gathered}
S C O P=\eta_{I I} \frac{\left(\Theta_{h}+273,2\right)}{\left(\Theta_{h}-\Theta_{c}\right)} \\
S E E R=\eta_{I I} \frac{\left(\Theta_{c}+273,2\right)}{\left(\Theta_{h}-\Theta_{c}\right)}
\end{gathered}
$$

Since the GSHPs cannot be auto sized in DesignBuilder, several steps are required for setting up these systems. The process is as follows:

- the design thermal (heating and cooling) loads of the building must be calculated;

- a correctly sized heat pump model from DesignBuilder database must be chosen considering both the peak heating and cooling loads. Another possibility is to create a new type of heat pump;

- the number of vertical boreholes is calculated.

The energy requirements are reported in terms of primary energy, using a conversion factor for electricity equal to 2,2 and a conversion factor for natural gas equal to 1,05. Currently, Italian legislation does not present any specific requirements for NZEB target. In fact, the D.M. 26/06/2015 (2015) establishes the standards to be reached in order to identify a building as nearly ZEB (nZEB), but not NZEB.

For this reason, following the Italian legislation (D.M. $26 / 06 / 2015$ ), first it has been verified if the examined building respects the constraints for the nZEB, which concern both the building envelope and the building energy systems, as follows:

a) global heat transfer coefficient: $\mathrm{H}_{\mathrm{T}} \leq$ reference value;

b) equivalent solar area of the windows: $\mathrm{A}_{\text {sol,equivest }} / \mathrm{A}_{\text {sup,utile }} \leq$ reference value;

c) energy performance indexes for the building envelope and systems $\left(\mathrm{EP}_{\mathrm{H}, \mathrm{nd}}, \mathrm{EP}_{\mathrm{C}, \mathrm{nd}}, \mathrm{EP}_{\text {glob,tot }}\right) \leq$ reference values; 
d) efficiencies of the systems ( $\mathrm{H}$ for heating, $\mathrm{C}$ for cooling, DHW for domestic hot water): $\eta_{\mathrm{H}}, \eta_{\mathrm{C}}, \eta_{\mathrm{DHW}}$ $\geq$ reference values.

Once verified that the considered building is a nearly ZEB, a renewable energy system (photovoltaic solar panels) was designed to obtain a Net ZEB. The total area of the panels was assessed considering alternatively an air-to-water heat pump, or a geothermal heat pump (GSHP), or a condensing boiler coupled to a chiller, to estimate if the GSHP would allow to reach the NZEB target with a significantly smaller photovoltaic surface.

There are various ways to carry out the energy balance for a NZEB (Bourelle et al, 2013; Hall et al, 2017). Considering the control volume that coincides with the entire building, the energy balance has been made between energy needs and energy production from renewable sources:

$$
E_{\text {needed }}-E_{\text {renewable, } \text { produced }}=0
$$

\section{Description of the case study}

The reference building is intended for bed and breakfast, virtually located in two Italian cities having different geographic and climatic conditions (Table 2).

Palermo (southern Italy) is characterised by very hot summers and mild winters, Milan (northern Italy) by hot summers and cold winters.

The building stands on two levels, with a total area of 310 $\mathrm{m}^{2}\left(900 \mathrm{~m}^{3}\right)$. To obtain a NZEB, attention is paid to the design of the building envelope (passive design). The sun position is considered (Figure 1): the living area is located to the South to take advantage of the solar gains in winter, while the sleeping area and some service rooms are located to the North. The position of the windows is chosen to maximize natural ventilation. Moreover, a compact form is designed, with a surface-area-to-volume ratio equal to $0,20 \mathrm{~m}^{-1}$. To reduce the thermal flows through the building envelope, very low unitary thermal transmittances of opaque and transparent components are chosen (Table 3), mainly for the coldest locality (Milan).

The design thermal (heating and cooling) loads of the building are calculated by the software and reported in the Table 4.

As known, for a NZEB the balance between the imported energy and the exported energy must be $0 \mathrm{kWh} / \mathrm{m}^{2} \mathrm{y}$. To this end, a good design of the building-plant system allows to minimize the energy demands. Therefore, it has been investigated which of the proposed thermal energy generators (air-to-water heat pump; geothermal heat pump; condensing boiler coupled to a chiller) allows the minimum energy demand that facilitates the achievement of the NZEB target. In the Table 5 the values of the seasonal average energy efficiency for the three proposed systems are reported.
Table 2: Geographic/climatic conditions of the chosen cities, from ASHRAE (2017) and DPR $412 / 93$ (1993).

\begin{tabular}{|c|c|c|c|c|c|}
\hline \multicolumn{6}{|c|}{ PALERMO } \\
\hline \multirow{2}{*}{ 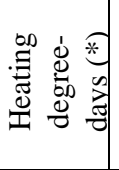 } & \multirow{2}{*}{ 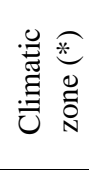 } & \multirow{2}{*}{ 莺 } & \multirow{2}{*}{ 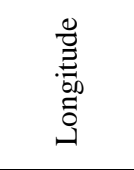 } & \multicolumn{2}{|c|}{$\begin{array}{c}\text { Outdoor reference } \\
\text { temperature }\end{array}$} \\
\hline & & & & Summer & Winter \\
\hline $\begin{array}{c}751 \\
\text { K·day }\end{array}$ & B & $\begin{array}{c}38^{\circ} 6^{\prime} \\
43^{\prime}, 56 \mathrm{~N}\end{array}$ & $\begin{array}{c}13^{\circ} 20^{\prime} 11 \\
, 76 \mathrm{E}\end{array}$ & $33,8^{\circ} \mathrm{C}$ & $6,6^{\circ} \mathrm{C}$ \\
\hline \multicolumn{6}{|c|}{ MILAN } \\
\hline \multirow{2}{*}{ 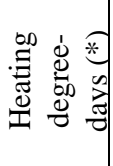 } & \multirow{2}{*}{ 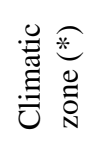 } & \multirow{2}{*}{ : } & \multirow{2}{*}{ 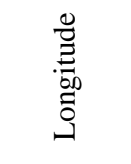 } & \multicolumn{2}{|c|}{$\begin{array}{c}\text { Outdoor reference } \\
\text { temperature }\end{array}$} \\
\hline & & & & Summer & Winter \\
\hline $\begin{array}{l}2404 \\
\text { K.day }\end{array}$ & E & $\begin{array}{c}45^{\circ} 28^{\prime} 38 \\
, \quad 28 \mathrm{~N}\end{array}$ & $\begin{array}{c}9^{\circ} 10^{\prime} \\
53 \text { ' } 40 \mathrm{E}\end{array}$ & $33,1^{\circ} \mathrm{C}$ & $-4,9^{\circ} \mathrm{C}$ \\
\hline
\end{tabular}

Table 3: U-values of the building envelope components $\left[\mathrm{W} / \mathrm{m}^{2} \mathrm{~K}\right]$.

\begin{tabular}{|c|c|c|}
\hline & Palermo & Milan \\
\hline Walls & 0,42 & 0,24 \\
\hline Roof & 0,33 & 0,21 \\
\hline Slab on the ground & 0,39 & 0,23 \\
\hline Windows & 2,05 & 1,20 \\
\hline
\end{tabular}

Table 4: Design thermal loads of the building.

\begin{tabular}{|c|c|c|c|c|c|}
\hline \multirow{2}{*}{ Volume } & \multicolumn{4}{|c|}{ Thermal (heating and cooling) loads } \\
\cline { 3 - 6 } & & \multicolumn{2}{|c|}{ Winter conditions } & \multicolumn{2}{|c|}{ Summer conditions } \\
\cline { 3 - 6 } & $\mathrm{m}^{3}$ & $\mathrm{~kW}$ & $\mathrm{~W} / \mathrm{m}^{3}$ & $\mathrm{~kW}$ & $\mathrm{~W} / \mathrm{m}^{3}$ \\
\hline \multirow{2}{*}{ Milan } & & 12 & 13 & 21 & 23 \\
\cline { 3 - 6 } Palermo & & 10 & 12 & 22 & 24 \\
\cline { 3 - 6 } & & & & & \\
\hline
\end{tabular}

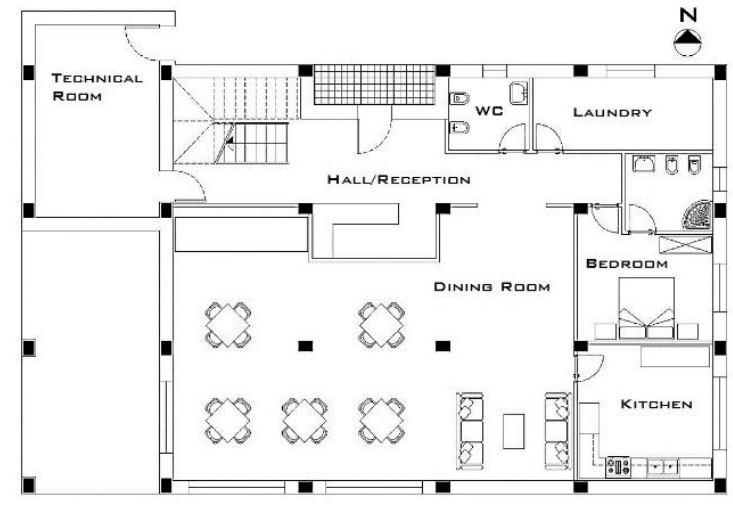

Figure 1a: Ground floor of the examined building. 


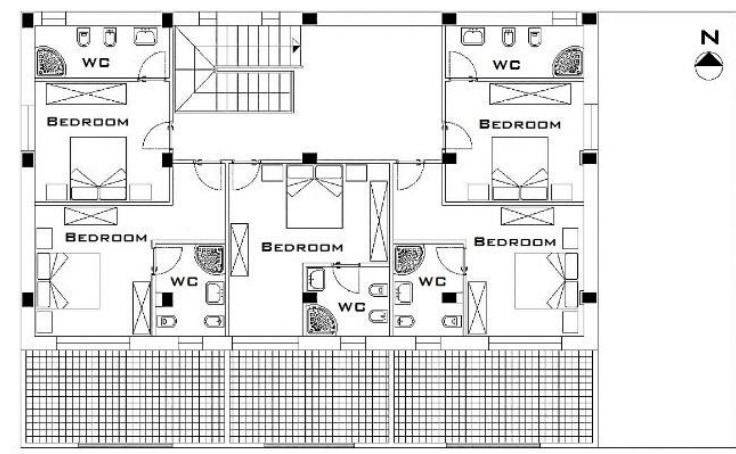

Figure 1b: First floor of the examined building.

Table 5: Seasonal average energy efficiency for the proposed systems.

\begin{tabular}{|l|c|c|c|c|}
\hline \multirow{2}{*}{} & \multicolumn{2}{|c|}{ Palermo } & \multicolumn{2}{c|}{ Milan } \\
\cline { 2 - 5 } & $\begin{array}{c}\text { Boiler } \\
\text { efficiency } \\
\text { or SCOP }\end{array}$ & $\begin{array}{c}\text { SEE } \\
\text { R }\end{array}$ & $\begin{array}{c}\text { Boiler } \\
\text { efficiency or } \\
\text { SCOP }\end{array}$ & $\begin{array}{c}\text { SEE } \\
\text { R }\end{array}$ \\
\hline Boiler + chiller & 0,90 & 4,90 & 0,90 & 4,80 \\
\hline $\begin{array}{l}\text { Air-to-water } \\
\text { Heat Pump }\end{array}$ & 4,80 & 4,90 & 4,10 & 4,80 \\
\hline $\begin{array}{l}\text { Ground Source } \\
\text { Heat Pump }\end{array}$ & 6,20 & 5,60 & 4,80 & 7,00 \\
\hline
\end{tabular}

Each proposed thermal energy generator is linked to an air handling unit (AHU) for primary air and to fan-coil units.

The design indoor air temperature is $20^{\circ} \mathrm{C}$ for winter and $26{ }^{\circ} \mathrm{C}$ for summer. The design temperature of the supply primary air is $24^{\circ} \mathrm{C}$ for heating and $12^{\circ} \mathrm{C}$ for cooling. With reference to the heating system, a different operating program has been set for the two locations examined, following also the indications of DPR 412/93 (1993):

- Palermo (climatic zone: B): from December 1st to March 3rd (6 hours, i.e.: 6:00 - 9:00 A.M., 6:00 11:00 P.M.);

- Milan (climatic zone: E): from October 15th to April 15th (14 hours, i.e.: 5:00 - 9:00 A.M., 12:00 A.M. 3:00 P.M., 5:00 - 12:00 P.M.).

With reference to the cooling system, the following operating periods have been considered:

- Palermo: from June 1st to September 30th (9 hours, i.e.: 11:00 A.M. - 4:00 P.M., 6:00 - 10:00 P.M.)

- Milan: from June 1st to September 30th (8 hours, i.e.:11:00 A.M. - 3:00 P.M., 6:00 - 10:00 P.M.)

Solar thermal panels (4 panels for Palermo and 5 for Milan) and a dedicated heat pump with a COP equal to 2,5 are considered to produce domestic hot water (DHW). The DHW consumption rate is equal to $2,5 \mathrm{l} / \mathrm{m}^{2}$ day.

The lighting system is characterised by LED devices with linear control $\left(2,5 \mathrm{~W} / \mathrm{m}^{2} 100 \mathrm{lux}\right)$. The design illuminance is 500 lux in the common spaces, 300 lux in the bedrooms. The presence of other electrical devices is scarce, therefore a power range between 1 and $4 \mathrm{~W} / \mathrm{m}^{2}$ is set.

\section{Results}

\section{Energy results}

The energy savings related to the use of a geothermal heat pump are evaluated, compared to both the solution with an air-to-water heat pump and that with a condensing boiler coupled to a chiller. The various primary energy requirements for different energy uses are reported in the Figures 2 and 3, for Palermo and Milan, respectively.

In the case of Palermo, as can be obtained from the values in Figure 2, the use of GSHP reduces the primary energy for heating plus cooling by $15 \%$ compared to an air-towater heat pump ( $23 \%$ when considering only heating, $12 \%$ for only cooling), by $38 \%$ compared to the solution with boiler and chiller.

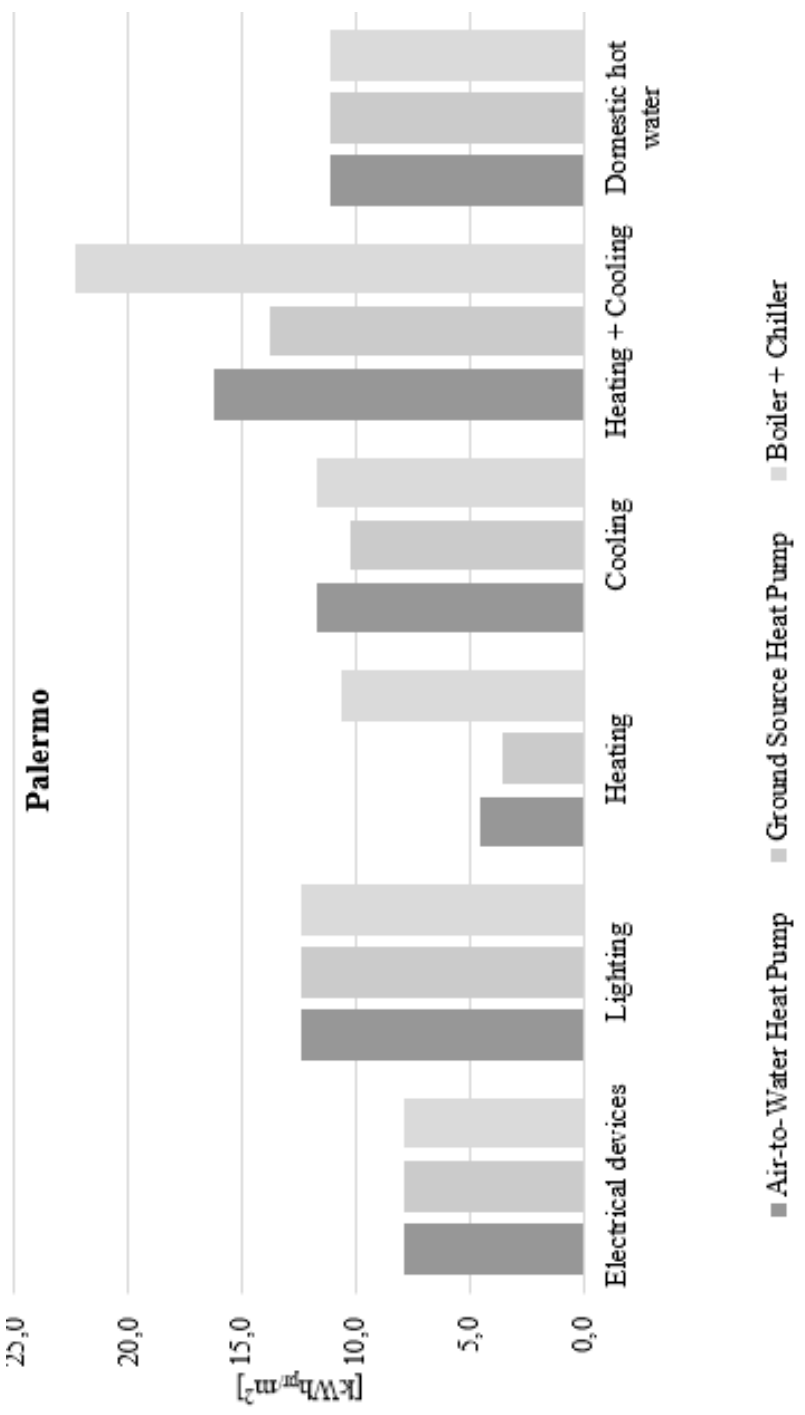

Figure 2: Primary energy requirements $\left(\mathrm{kWh} / \mathrm{m}^{2} \mathrm{y}\right)$ for Palermo for the three different proposed systems. 
With reference to the global annual primary energy requirements (Figure 4), the saving related to the GSHP is $5 \%$ compared to the air-to-water heat pump, $16 \%$ compared to boiler plus chiller.

The electricity annual requirement changes from a value of $6131 \mathrm{kWh} / \mathrm{y}\left(20 \mathrm{kWh} / \mathrm{m}^{2} \mathrm{y}\right)$ obtained using an air-towater heat pump to a value of $5810 \mathrm{kWh} / \mathrm{y}$ using a GSHP $(-5 \%)$.

In the case of Milan (cold winters), as can be obtained from the values in Figure 3, the use of GSHP reduces the primary energy for heating plus cooling by $19 \%$ compared to an air-to-water heat pump (15\% referred to only heating, $31 \%$ for only cooling), by $53 \%$ compared to the solution with boiler and chiller. With reference to the global annual primary energy requirements (Figure 5), the saving related to the GSHP is $9 \%$ compared to the air-towater heat pump, $31 \%$ compared to boiler plus chiller.

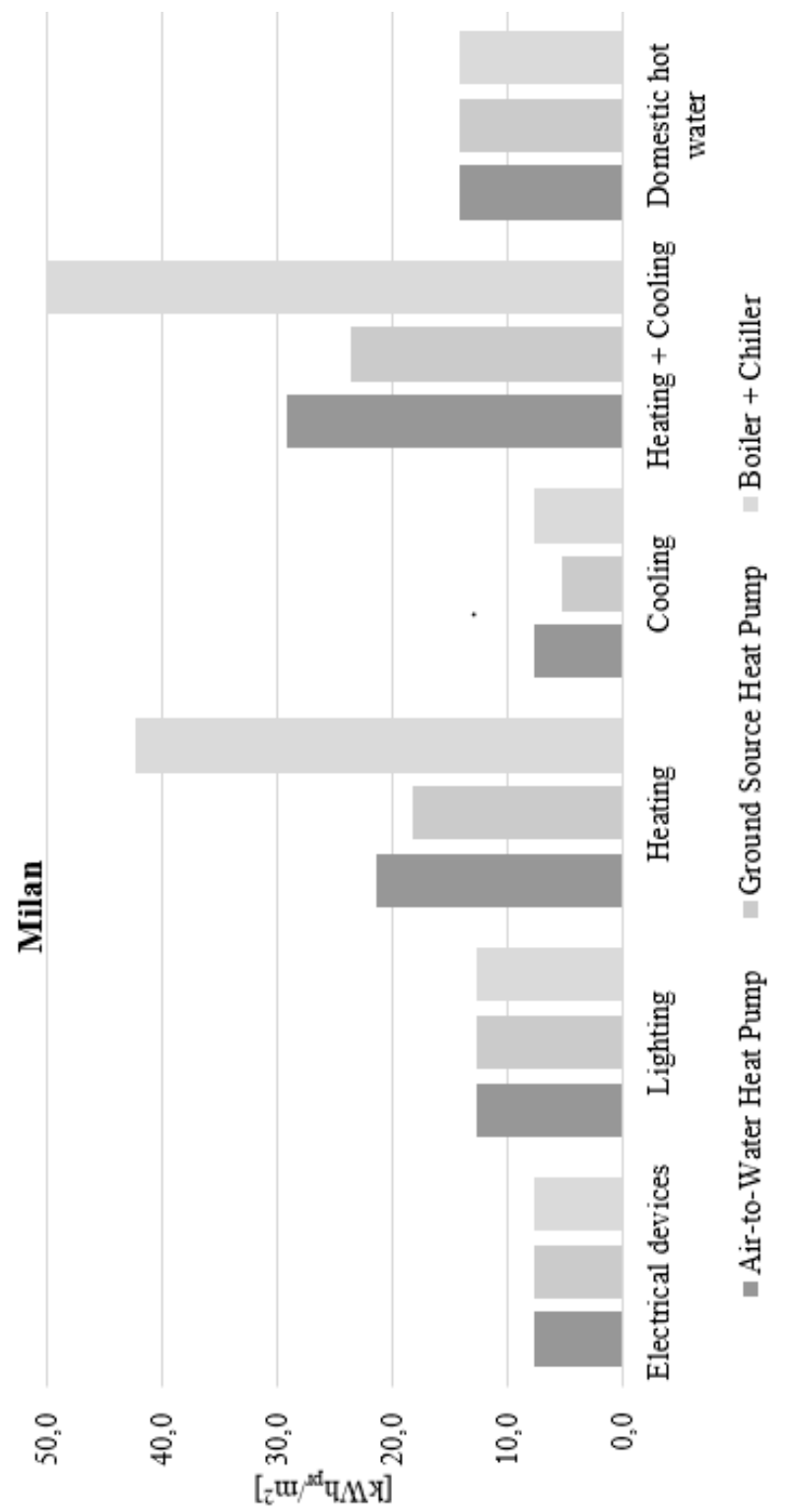

Figure 3: Primary energy requirements $\left(\mathrm{kWh} / \mathrm{m}^{2} \mathrm{y}\right)$ for Milan for the three different proposed systems.
In this case, the electricity requirement when using a GSHP is $7459 \mathrm{kWh} / \mathrm{y}\left(24 \mathrm{kWh} / \mathrm{m}^{2} \mathrm{y}\right)$ versus $8171 \mathrm{kWh} / \mathrm{y}$ $\left(26 \mathrm{kWh} / \mathrm{m}^{2} \mathrm{y}\right)$ using an air-to-water heat pump, i.e. - $9 \%$.

As can be seen in the Figures 4 and 5, the global primary energy demand for both cities is very low and varies between $45 \mathrm{kWh} / \mathrm{m}^{2} \mathrm{y}$ and $54 \mathrm{kWh} / \mathrm{m}^{2} \mathrm{y}$ for Palermo, 58$85 \mathrm{kWh} / \mathrm{m}^{2} \mathrm{y}$ for Milan.

Interesting primary energy savings are obtained for heating plus cooling when using GSHP compared to airto-water heat pump (16-19\%) or boiler coupled to chiller (38-53\%), mainly for the coldest climate (Milan, 53\%).

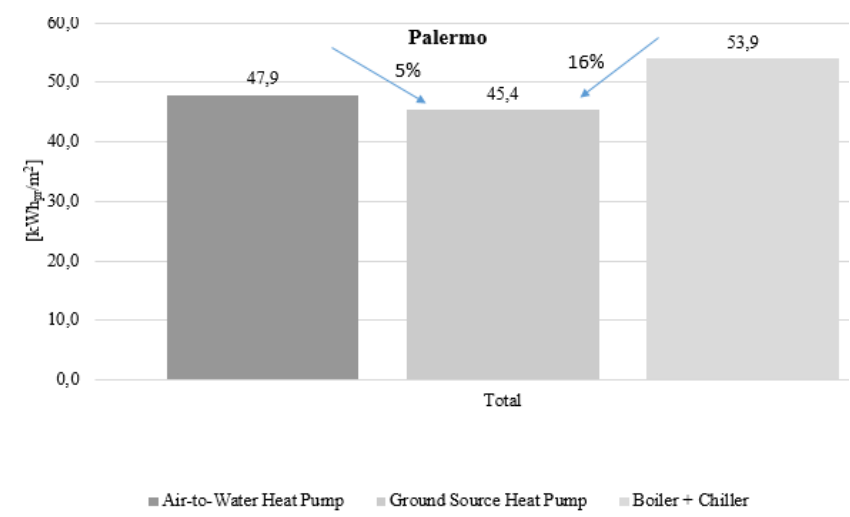

Figure 4: Global primary energy requirements $\left(\mathrm{kWh} / \mathrm{m}^{2} \mathrm{y}\right)$ for Palermo for the three proposed systems.

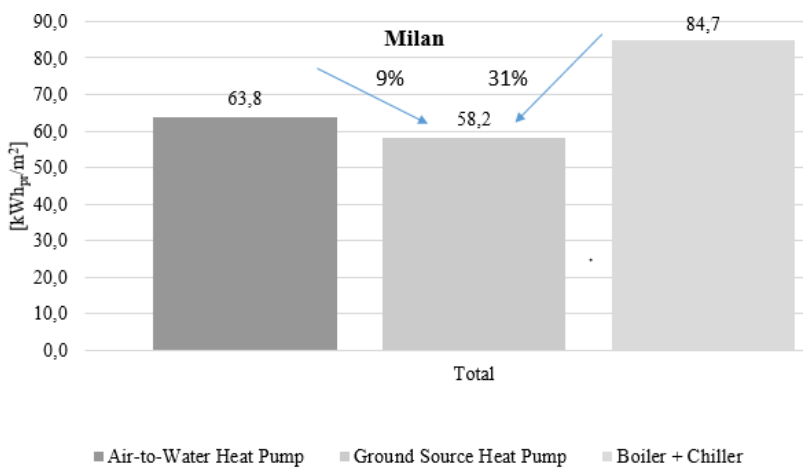

Figure 5: Global primary energy requirements $\left(\mathrm{kWh} / \mathrm{m}^{2} \mathrm{y}\right)$ for Milan for the three proposed systems.

In Tables 6 and 7 all the energy balances and the number of PV and solar thermal panels for each case are shown, for Palermo and Milan, respectively. The following procedure has been applied to reach the NZEB target:

- in the cases characterized by only electric energy requirements (GSHP; air-to-water heat pump), the annual electric energy required by all the building systems must be balanced by the annual electric energy produced by the PV panels;

- in the case characterized by both electric energy and natural gas requirements (boiler plus chiller), the annual electric energy required by all the building 
systems must be balanced by the annual electric energy produced by the PV panels, while the annual energy related to the natural gas required by the boiler (3147 $\mathrm{kWh}$ for Palermo) is first reported in primary energy $\left(3304 \mathrm{kWh}_{\mathrm{pr}}\right)$ and this must be balanced by the annual electric energy produced by the PV panels (3446 kWh - this electric energy is equal to the primary energy in the case of PV panels).

For Palermo, the NZEB target is verified considering 7 photovoltaic panels ( $300 \mathrm{~W}_{\text {peak }}$ per panel) in the best case (GSHP), 11 panels in the case of condensing boiler plus chiller. Referring to Milan, given the greater energy demand due to air conditioning, the energy saving leads to a sharp reduction in the surface necessary to PV panels. In fact, using a GSHP, the target NZEB is obtained with 12 photovoltaic panels ( $300 \mathrm{~W}_{\text {peak }}$ per panel), versus 29 in the worst case (boiler plus chiller). This means a saving of $59 \%$ referring to the photovoltaic surface.

Since in the current Italian laws it is not provided any verification that certifies the achievement of NZEB target, for each case the correspondence to the minimum requisites for a nearly ZEB has been at least verified, by means of TERMOLOG software (2018), and the percentage of renewable energy exploited by the different technologies has been obtained: for both the localities, $81 \%$ in the case of GSHP, $75-76 \%$ for the air-to-water heat pump and 63-64\% for the boiler plus chiller.

\section{Economic results}

An energetic-economic analysis of the three solutions has been also carried out, in terms of both Simple PayBack (SPB) and Discounted PayBack (DPB) periods (Tables 8 and 9).

For this purpose, the investment costs of the three solutions have been calculated. The most advantageous comparison from an economic point of view is the one between the GSHP and the solution with boiler plus chiller, due to greater energy savings. In fact, in this case, the additional cost of the investment is recovered in only 3 years for Milan (DPB) and about 13 years for Palermo.

Table 6: Annual energy balances for NZEB in Palermo.

\begin{tabular}{|c|c|c|c|c|c|}
\hline \multicolumn{6}{|c|}{ PALERMO } \\
\hline & & & \multicolumn{3}{|c|}{$\begin{array}{c}\text { PV PANELS } \\
(0,3 \text { kWp per panel })\end{array}$} \\
\hline & 惡 & 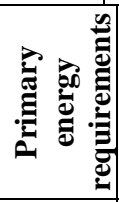 & 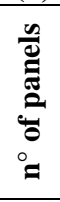 & 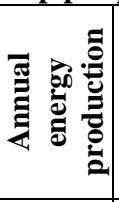 & $\begin{array}{l}\text { NZEB } \\
\text { target }\end{array}$ \\
\hline & {$[k W h]$} & {$\left[k W h_{p r}\right]$} & {$[-]$} & {$[k W h]$} & {$[-]$} \\
\hline \multirow{2}{*}{$\begin{array}{l}\text { Boiler } \\
\text { chiller }\end{array}$} & 3147 & 3304 & 4,0 & 3446 & \multirow{2}{*}{$\checkmark$} \\
\hline & 5541 & & 7,0 & 6031 & \\
\hline $\begin{array}{c}\text { Air-to- } \\
\text { water heat } \\
\text { pump } \\
\end{array}$ & 6131 & & 8,0 & 6892 & $\checkmark$ \\
\hline $\begin{array}{c}\text { Ground } \\
\text { source } \\
\text { heat pump }\end{array}$ & 5811 & & 7,0 & 6031 & $\checkmark$ \\
\hline
\end{tabular}

Table 7: Annual energy balances for NZEB in Milan.

\begin{tabular}{|c|c|c|c|c|c|}
\hline \multicolumn{6}{|c|}{ MILAN } \\
\hline & & & \multicolumn{3}{|c|}{$\begin{array}{c}\text { PV PANELS } \\
(0,3 \text { kWp per panel }) \\
\end{array}$} \\
\hline & 焉苞总 & 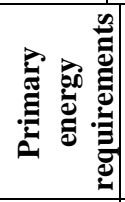 & 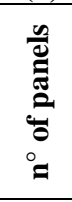 & 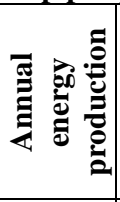 & $\begin{array}{l}\text { NZEB } \\
\text { target }\end{array}$ \\
\hline & {$[\mathrm{kWh}]$} & {$\left[k W h_{p r}\right]$} & {$[-]$} & {$[\mathrm{kWh}]$} & {$[-]$} \\
\hline \multirow{2}{*}{$\begin{array}{l}\text { Boiler } \\
\text { chiller }\end{array}$} & 12488 & 13113 & 20,0 & 13310 & \multirow{2}{*}{$\checkmark$} \\
\hline & 5431 & & 9,0 & 5990 & \\
\hline $\begin{array}{c}\text { Air-to- } \\
\text { water heat } \\
\text { pump }\end{array}$ & 8171 & & 13,0 & 8652 & $\checkmark$ \\
\hline $\begin{array}{l}\text { Ground } \\
\text { source } \\
\text { heat pump }\end{array}$ & 7459 & & 12,0 & 7986 & $\checkmark$ \\
\hline
\end{tabular}

Table 8: SPB and DPB for the different solutions in the case of Palermo.

\begin{tabular}{|c|c|c|c|}
\hline \multicolumn{4}{|c|}{ PALERMO } \\
\hline \multicolumn{4}{|c|}{ Air to water heat pump compared to boiler + chiller: } \\
\hline Additional cost & Saving & SPB & DPB \\
\hline$[€]$ & {$[€]$} & [years] & [years] \\
\hline 0 & 182 & - & - \\
\hline \multicolumn{4}{|c|}{ GSHP heat pump compared to boiler + chiller: } \\
\hline Additional cost & Saving & SPB & DPB \\
\hline$[€]$ & {$[€]$} & [years] & [years] \\
\hline 2273 & 254 & 9 & 13 \\
\hline \multicolumn{4}{|c|}{ GSHP compared to air-to-water heat pump: } \\
\hline Additional cost & Saving & SPB & DPB \\
\hline$[€]$ & {$[€]$} & [years] & [years] \\
\hline 3123 & 72 & 43 & $>50$ \\
\hline
\end{tabular}

The comparison between the GSHP and the air-to-water heat pump is less convenient: in both the cases of Milan and Palermo, the investment is recovered in more than 50 years. Therefore, the air-to-water heat pump seems more convenient than geothermal one from an economic point of view. However, it should be noted that the air-to-water heat pump, especially in cold climates (Milan), can be affected by a malfunction. In fact, in the case of very low external temperatures, it may sometimes not satisfy the user. 
Table 9: $S P B$ and DPB SPB and DPB for the different solutions in the case of Milan.

\begin{tabular}{|c|c|c|c|}
\hline \multicolumn{4}{|c|}{ MILAN } \\
\hline \multicolumn{4}{|c|}{ Air to water heat pump compared to boiler + chiller: } \\
\hline Additional cost & Saving & SPB & DPB \\
\hline [€] & {$[€]$} & [years] & [years] \\
\hline 0 & 632 & - & - \\
\hline \multicolumn{4}{|c|}{ GSHP heat pump compared to boiler + chiller: } \\
\hline Additional cost & Saving & SPB & DPB \\
\hline [€] & {$[€]$} & [years] & [years] \\
\hline 2084 & 793 & 3 & 3 \\
\hline \multicolumn{4}{|c|}{ GSHP compared to air-to-water heat pump: } \\
\hline Additional cost & Saving & SPB & DPB \\
\hline [€] & {$[€]$} & [years] & [years] \\
\hline 3684 & 160 & 23 & $>50$ \\
\hline
\end{tabular}

\section{Conclusions}

In this article the energy contribution of a geothermal heat pump in a NZEB is evaluated. The comparison is made with both an air-to-water heat pump and a condensing boiler coupled to a chiller.

The comparison shows that the geothermal heat pump, compared to the air-to-water heat pump, allows significant energy savings for heating and cooling $(23 \%$ and $12 \%$ for Palermo, respectively; $15 \%$ and $31 \%$ for Milan), but these savings decrease when considering the global energy requirements (around 5\% for Palermo and $9 \%$ for Milan).

Considering the energy requirements for heating plus cooling, interesting savings are obtained when using GSHP: $16-19 \%$ compared to the air-to-water heat pump, $38-53 \%$ compared to boiler coupled to chiller (53\% for the coldest climate, i.e. Milan).

The energy saving related to the use of the GSHP is even more advantageous when compared to the solution based on condensing boiler and chiller: with reference to the global energy requirements, this saving is $16 \%$ for Palermo, $31 \%$ for Milan.

The energy contribution of the GSHP in a NZEB is not negligible, since the photovoltaic surface is significantly reduced, especially in cold climate and in the comparison with the condensing boiler plus chiller: the number of photovoltaic panels decreases from 29 to 12 for Milan (11 to 7 for Palermo). This result is important, particularly for existing buildings, due to the limited area available to exploit on-site renewable energy sources. In the definition of a NZEB, if the energy balance is made considering the control volume delimited by the physical boundaries of the building, the above-mentioned savings can be significant.

From an economic point of view, the DPB for the GSHP is around 3 years for Milan, 13 years for Palermo when compared to the solution with condensing boiler plus chiller, more than 50 years when compared to an air-towater heat pump. Although the use of the air-to-water heat pump seems more suitable from an economic point of view, it should be noted that, especially in cold climates (like Milan), it can be affected by a malfunction. In fact, in the case of very low external temperatures, it may sometimes not satisfy the user.

Moreover, for both the localities, the GSHP uses a higher rate of renewable energy ( $81 \%$ for GSHP, versus $75-76 \%$ for air-to-water heat pump and $63-64 \%$ in the case of boiler plus chiller).

\section{Acknowledgement}

The authors would like to thank Dr Cristina Ancona of Logical Soft for the use of the TERMOLOG software.

\section{Nomenclature}

\section{AHU: Air Handling Unit}

DHW: Domestic Hot Water

DPB: Discounted Payback period [years]

$\mathrm{EP}_{\mathrm{C}, \mathrm{nd}}$ : Thermal energy requirements for the building cooling $\left[\mathrm{kWh} / \mathrm{m}^{2} \mathrm{y}\right]$

$\mathrm{EP}_{\mathrm{H}, \mathrm{nd}}$ : Thermal energy requirements for the building heating $\left[\mathrm{kWh} / \mathrm{m}^{2} \mathrm{y}\right]$

$\mathrm{EP}_{\text {glob,tot: }}$ Primary energy requirements of the building energy systems $\left[\mathrm{kWh} / \mathrm{m}^{2} \mathrm{y}\right]$

GSHP: Ground Source Heat Pump

HVAC: Heating Ventilation and Air Conditioning

NZEB: Net Zero Energy Building

nZEB: nearly Zero Energy Building

E: Energy [kWh]

PV: Photovoltaic

SCOP: Seasonal Coefficient of Performance

SEER: Seasonal Energy Efficiency Ratio

SPB: Single Payback period [years]

$\mathrm{U}$ : Unitary thermal transmittance $\left[\mathrm{W} / \mathrm{m}^{2} \mathrm{~K}\right]$

$\eta_{\text {II: }}$ second law efficiency

$\theta_{\mathrm{c}}$ : temperature of the cold sink $[\mathrm{K}]$

$\theta_{\mathrm{h}}$ : temperature of the hot sink $[\mathrm{K}]$

Subscript - pr: referred to primary energy

\section{References}

Ascione, F., D’Agostino, D., Marino, C. and Minichiello, F. (2016). Earth-to-air heat exchanger for NZEB in Mediterranean Climate. Renewable Energy 99, 553563.

ASHRAE. International Weather files for Energy Calculations (IWEC weather files). User's manual and 
CD-ROM, American Society of Heating, Refrigerating and Air-Conditioning Engineers, Atlanta, GA, USA, 2017

Bourelle, J.S., Andresen, I. and Gustavsen A. (2013). Energy payback: An attributional and environmentally focused approach to energy balance in net zero energy buildings. Energy and Buildings 65, 84-92.

Buonomano, A., De Luca, G., Montanaro, U. and Palombo, A. (2016). Innovative technologies for NZEBs: An energy and economic analysis tool and a case study of a non-residential building for the Mediterranean climate. Energy and Buildings 121, 318-343.

D’Agostino, D., Marino, C., Minichiello, F. and Russo, F. (2017). Obtaining a NZEB in Mediterranean Climate by using only on-site renewable energy: is it a realistic goal? Proceedings from 50th AiCARR International Congress on Beyond NZEB Buildings; Matera (IT), 10-11 May 2017.

DesignBuilder V.5.5.2.003

D.M. 26 giugno 2015, Applicazione delle metodologie di calcolo delle prestazioni energetiche e definizione delle prescrizioni e dei requisiti minimi degli edifici (in Italian).

DOE-2 Building Energy Use and Cost Analysis Tool, 2016. Available on-line: http://doe2.com/DOE2/index.html

D.P.R. 26 agosto 1993, n. 412, Regolamento recante norme per la progettazione, l'installazione, l'esercizio e la manutenzione degli impianti termici degli edifici, in attuazione dell'art. 4, comma 4, della L. 9 gennaio 1991, n. 10 (in Italian).

European Directive 2002/91/EC of the European Parliament and of the Council of 16 December 2002 on the energy performance of buildings - EPBD. https://eur-lex.europa.eu/legalcontent/EN/TXT/?uri=CELEX\%3A32002L0091

European Directive 2010/31/EU of the European Parliament and of the Council of 19 May 2010 on the energy performance of buildings - EPBD recast. https://eurlex.europa.eu/LexUriServ/LexUriServ.do?uri=OJ:L: 2010:153:0013:0035:en:PDF

European Directive 2018/844 https://eurlex.europa.eu/legalcontent/EN/TXT/?uri=u riserv\%3AOJ.L_.2018.156.01.0075.01.ENG

Ferrante, A. and Cascella, M.T. (2011). Zero energy balance and zero on-site $\mathrm{CO} 2$ emission housing development in the Mediterranean climate. Energy and Buildings 43, 2002-2010.

Fedajev, J., Simon, R., Kurnitski, J., Kesti, J., Mononen T., Petteri, L. (2016). Geothermal Heat Pump Plant Performance in a Nearly Zero-energy Building.
Proceedings from SBE16 Tallinn and Helsinki Conference; Build Green and Renovate Deep; Tallinn and Helsinki (FI), 5-7 October 2016.

Hall, M. and Geissler A. (2017) Different balancing methods for Net Zero Energy Buildings-Impact of time steps, grid interaction and weighting factors. Proceedings from CISBAT 2017 International Conference; Future building \& districts - Energy efficiency from nano to urban scale; Lausanne $(\mathrm{CH})$, 6-8 September 2017.

Hermelink, A., Schimschar, S., Boermans, T., Pagliano, L., Zangheri, P., Armani, R., Voss, K., Musall, E. (2013). Towards nearly zero-energy buildings. Definition of common principles under the EPBD. Final report. Project number: BESDE10788.

Jones, A. T., Finn, D., P. (2013). Ground source heat pump modelling with thermal storage-simulation and integration issues in EnergyPlus. Proceedings of BS2013; $13^{\text {th }}$ Conference of International Building Performance Simulation Association; Chambéry (FR), 26-28 August 2013.

Kusuda, T., and Archenbach, P.R. (1965). Earth Temperature and Thermal Diffusivity at Selected Stations in the United States, ASHRAE Transactions, Vol. 71, Part 1

Mohamed, A., Hasa \&, Sirén, K. (2014). Fulfilment of net-zero energy building (NZEB) with four metrics in a single family house with different heating alternatives. Applied Energy 114, 385-399.

TERMOLOG version Epix 8 (2018). Logical Soft.

Tang, C.C. (2005). Modeling packaged heat pumps in a quasi-steady state energy simulation program. Master of Science. Oklahoma: Department of Mechanical and Aerospace Engineering, Oklahoma State University.

TARP Thermal Analysis Research Program 2018. Available on-line: https://bigladdersoftware.com/epx/docs/90/engineering-reference/outside-surface-heatbalance.html\#tarp-algorithm-000

Torcellini, P., Pless, S., Deru, M., Drury, C. (2006). Zero energy buildings: a critical look at the definition. National Renewable Energy Laboratory report: NREL/CP-550-39833-June, 2006. https://www.nrel.gov/docs/fy06osti/39833.pdf

U.S. Department of Energy-a. EnergyPlus Testing with Building Thermal Envelope and Fabric Load Tests from ANSI/ASHRAE Standard 140-2011; 2011, 1-32, http://apps1.eere.energy.gov/buildings/energyplus/en ergyplus_testing.cfm.

U.S. Department of Energy-b. EnergyPlus Testing with HVAC Equipment Performance Tests from ANSI/ASHRAE Standard 140-2011; 2011, 1-80, http://apps1.eere.energy.gov/buildings/energyplus/en ergyplus_testing.cf 